\title{
Clinical Practice Guidelines for Diagnosis and Management of Hypersensitivity Reactions to Contrast Media
}

\author{
Rosado Ingelmo A', Doña Diaz I², Cabañas Moreno $\mathrm{R}^{3}$, Moya Quesada $\mathrm{MC}^{4}$, \\ García-Avilés $\mathrm{C}^{5}$, García Nuñez ${ }^{6}$, Martínez Tadeo $\mathrm{JI}^{7}$, Mielgo Ballesteros $\mathrm{R}^{8}$, \\ Ortega-Rodríguez $\mathrm{N}^{9}$, Padial Vilchez $\mathrm{MA}^{10}{ }^{10}$, Sánchez-Morillas L ${ }^{11}$, \\ Vila Albelda $\mathrm{C}^{1}$, Moreno Rodilla $\mathrm{E}^{12 *}$, Torres Jaén $\mathrm{MJ}^{2 *}$
}

\author{
'Unidad de Alergia, Hospital Universitario Fundación Alcorcón, Alcorcón, Madrid, Spain \\ ${ }^{2}$ Allergy Unit, IBIMA-Regional University Hospital of Málaga, UMA, Málaga, Spain \\ ${ }^{3}$ Department of Allergy, Hospital La Paz, Health Research Institute (IdiPAZ), Madrid, Spain \\ ${ }^{4}$ Sección de Alergia CH Torrecárdenas, Almería, Spain \\ 5 Unidad de Alergia, Hospital Moncloa, Madrid, Spain \\ ${ }^{6}$ Servicio de Alergología, Hospital Quirón Málaga, Málaga, Spain \\ ${ }^{7}$ Servicio de Alergología, Hospital Universitario Ntra Sra de Candelaria, Santa Cruz de Tenerife, Tenerife, Spain \\ ${ }^{8}$ Servicio de Alergología, Hospital Universitario 12 de Octubre, Madrid, Spain \\ ${ }^{9}$ Servicio de Alergia, Hospital Universitario de Gran Canaria Dr Negrín, Las Palmas de Gran Canaria, Spain \\ ${ }^{10}$ Servicio de Alergologia, Hospital Infanta Sofía, San Sebastián de los Reyes, Madrid, Spain \\ "Servicio de Alergologia, Hospital Clínico San Carlos, Madrid, Spain \\ ${ }^{12}$ Servicio de Alergología, Complejo Asistencial Universitario de Salamanca, Salamanca, Spain \\ *Both authors contributed equally to this study. \\ On behalf of the Drug Allergy Committee of Spanish Society of Allergy and Clinical Immunology (SEAIC)
}

J Investig Allergol Clin Immunol 2016; Vol. 26(3): 144-155

doi: 10.18176/jiaci.0058

\section{Abstract}

The objective of these guidelines is to ensure efficient and effective clinical practice. The panel of experts who produced this consensus document developed a research protocol based on a review of the literature.

The prevalence of allergic reactions to iodinated contrast media (ICM) is estimated to be $1: 170000$, that is, $0.05 \%-0.1 \%$ of patients undergoing radiologic studies with ICM (more than 75 million examinations per year worldwide). Hypersensitivity reactions can appear within the first hour after administration (immediate reactions) or from more than 1 hour to several days after administration (nonimmediate or delayed reactions). The risk factors for immediate reactions include poorly controlled bronchial asthma, concomitant medication (eg, angiotensin-converting enzyme inhibitors, B-blockers, and proton-pump inhibitors), rapid administration of the ICM, mastocytosis, autoimmune diseases, and viral infections.

The most common symptoms of immediate reactions are erythema and urticaria with or without angioedema, which appear in more than $70 \%$ of patients. Maculopapular rash is the most common skin feature of nonimmediate reactions (30\%-90\%).

Skin and in vitro tests should be performed for diagnosis of both immediate and nonimmediate reactions. The ICM to be administered will therefore be chosen depending on the results of these tests, the ICM that induced the reaction (when known), the severity of the reaction, the availability of alternative ICM, and the information available on potential ICM cross-reactivity.

Another type of contrast media, gadolinium derivatives, is used used for magnetic resonance imaging. Although rare, IgE-mediated reactions to gadolinium derivatives have been reported.

Key words: Iodinated. Gadolinium. Contrast media. Allergy. Hypersensitivity. Anaphylaxis. Immediate reactions. Nonimmediate reactions. 


\section{Resumen}

El contenido y las pautas recomendadas en este documento están dirigidas a lograr una práctica clínica más eficiente y eficaz. El panel de expertos que participó en esta guía de consenso desarrolló un protocolo para revisar lo publicado sobre el tema.

La prevalencia de las reacciones alérgicas a medios de contraste iodados ( $\mathrm{MCl}$ ) se estima en 1:170.000, lo que representa un 0,05\% $-0,1 \%$ de los pacientes sometidos a estudios radiológicos con $\mathrm{MCl}$ (más de 75 millones de administraciones por año en todo el mundo). Las reacciones alérgicas por hipersensibilidad pueden aparecer dentro de la primera hora tras la administración (reacciones inmediatas) o en un rango de tiempo desde una hora hasta varios días después de la administración (reacciones no inmediatas o tardías). Existen factores de riesgo para las reacciones inmediatas tales como: mal control previo del asma bronquial, uso concomitante de inhibidores de la ECA, beta bloqueantes o inhibidores de la bomba de protones, administración rápida del fármaco, antecedente de mastocitosis, coexistencia de enfermedades autoinmunes o de infecciones virales.

Los síntomas más comunes de las reacciones inmediatas son eritema y urticaria con o sin angioedema, apareciendo en más de un $70 \%$ de los pacientes que sufrieron reacciones. Las reacciones no inmediatas más comunes son las erupciones maculopapulares (30-90\%). Para el diagnóstico de reacciones tanto inmediatas como no inmediatas se deben realizar pruebas cutáneas y pruebas in vitro. Para elegir el $\mathrm{MCl}$ que posteriormente puede ser administrado se tendrán en cuenta los resultados de las pruebas cutáneas e in vitro realizadas, el $\mathrm{MCl}$ que indujo la reacción (si se conoce), la gravedad de la misma, la disponibilidad de otros MCls alternativos y la información disponible sobre la potencial reactividad cruzada entre los distintos MCls.

Otro tipo de medios de contraste, son los utilizados en la resonancia magnética (RMN), que son derivados de gadolinio. Aunque infrecuentes, se han descrito reacciones mediadas por lgE a estos medios de contraste.

Palabras clave: Iodinado. Gadolinio. Medios de contraste. Alergia. Hipersensibilidad. Anafilaxia. Reacciones inmediatas. Reacciones no inmediatas.

\section{Prologue}

The objective of these guidelines is to ensure efficient and effective clinical practice in the diagnosis and management of hypersensitivity reactions to radiologic contrast media. The guidelines were developed by a panel of allergy specialists from the Drug Allergy Committee of the Spanish Society of Allergy and Clinical Immunology (SEAIC) with extensive clinical expertise in the evaluation and management of hypersensitivity reactions and broad research experience.

We performed a systematic and independent review of the literature up to November 2015 and established a consensus of expert opinion. We evaluated the applicability of the guidelines in our daily clinical practice. The guidelines were evaluated and criticized by external reviewers with expertise in the field.

\section{Method}

The panel of experts who produced this consensus document developed a research protocol outlining the background to the subject of study, the objectives of the study, and the questions and hypotheses from which search criteria were defined.

The main sources used for the literature search included electronic databases and archives (MEDLINE-PubMed, Science Direct, OVID) and a database of systematic reviews (Cochrane Library).

Search criteria were established to facilitate the identification of items relating to definitions, prevalence, classification, clinical manifestations, diagnosis, treatment, and prevention of the various types of reactions to contrast media. The keywords for radiologic contrast media-iodinated, ionic, nonionic, monomeric, dimeric, and gadolinium - were combined with the words allergy, hypersensitivity, anaphylaxis, and immediate and non-immediate reactions.
We selected only original research articles or systematic reviews.

Grades of recommendation were defined according to the Scottish Intercollegiate Guidelines Network [1].

\section{Introduction}

Iodinated contrast media (ICM) were introduced into clinical practice in the early twentieth century [2-4]. However, their application was initially limited owing to poor radiopacity and toxicity $[5,6]$. In the 1950 s, ICM were increasingly used thanks to new formulations with higher resolution and lower toxicity. In the 1970 s, nonionic dimeric ICM and derivatives with higher physiological osmolality [7] were developed. Nowadays, ICM are administered more than 75 million times per year worldwide [8,9].

Adverse reactions to ICM are not uncommon, but they are usually mild and caused by toxicity or hypersensitivity. Reactions are often underreported, and severe reactions may not always be recorded [10,11]. Hypersensitivity reactions can appear within the first hour after administration (immediate reactions) or more than 1 hour to several days after administration (nonimmediate or delayed reactions) [12]. Immediate reactions have long been attributed to non-IgEmediated mechanisms [9], although there is growing evidence that tryptase levels increase after the reaction. Furthermore, positive skin test or basophil activation test results could support an IgE-mediated mechanism in some cases [13-17]. The prevalence of nonimmediate hypersensitivity reactions has increased significantly in the last decade, whereas that of immediate reactions has decreased, with the result that nonimmediate reactions are now more frequent than immediate reactions [18]. Nonimmediate reactions can occur at least 1 hour after administration, although they usually appear after 24-48 hours and potentially after even longer periods [19]. A 
significant percentage of reactions to ICM are true allergic reactions requiring careful and adequate management, and in many instances, patients must undergo repeated testing with ICM. Not performing ICM studies could imply more risk than benefit.

Contrast media are also used for magnetic resonance imaging (MRI) to improve the visibility of internal structures. Their application has increased markedly in recent years, with gadolinium derivatives being the most frequent. Although rare, $\mathrm{IgE}$-mediated reactions to MRI contrast media have been reported [20-23].

\section{Classification and Physicochemical Properties of ICM}

ICM are iodine salts whose basic chemical structure comprises a benzene ring with at least 3 iodine atoms (triiodobenzene). The number of iodine atoms in each molecule is responsible for producing radiopacity [24]. ICM can be classified as having a monomeric structure if they have a benzene ring or a dimeric structure if the benzoic nucleus is covalently bound. The attachment of structural elements to the benzene ring determines their pharmacological and physicochemical characteristics.

An ICM is ionic if it transforms into ions or charged particles in aqueous solution or nonionic if it does not form ions, remaining instead an electrically neutral particle in solution. The ionization capacity of a given medium is directly related to the frequency and severity of the adverse reaction.

ICM can also be classified according to osmolality (the number of particles generated in solution) into highosmolality ICM ( $\left.\geq 1400 \mathrm{mOsm} / \mathrm{kg} \mathrm{H}_{2} \mathrm{O}\right)$, low-osmolality ICM (500-900 $\left.\mathrm{mOsm} / \mathrm{kg} \mathrm{H}_{2} \mathrm{O}\right)$, and isosmolar ICM (290 $\mathrm{mOsm} / \mathrm{kg} \mathrm{H}_{2} \mathrm{O}$ ) [25].

The viscosity of ICM is directly associated with the size of the molecule, the iodine concentration, and an increase in the frequency of delayed adverse effects. However, since viscosity decreases with increasing temperature, it can be

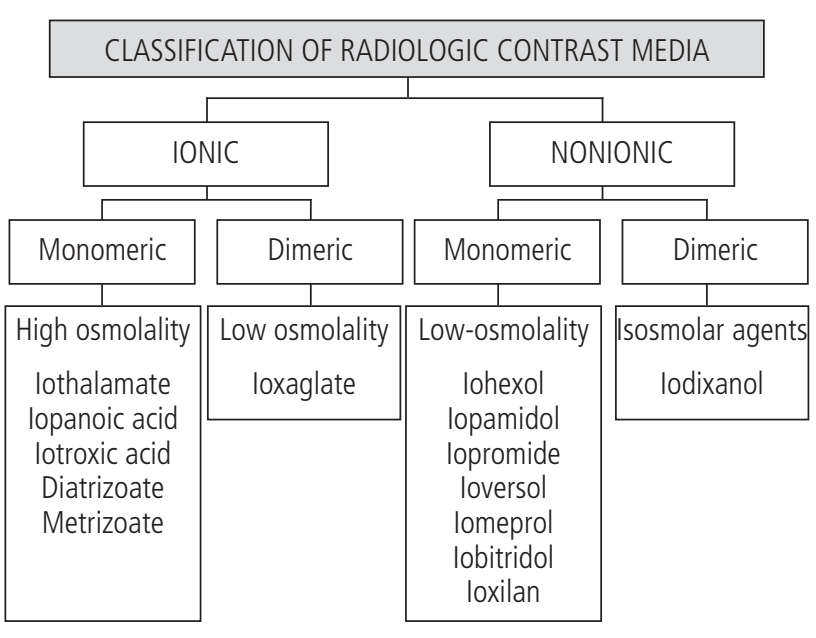

Figure 1. Classification of iodinated contrast media. reduced by heating the ICM to body temperature $\left(37^{\circ} \mathrm{C}\right)$ before administration [26].

ICM can be classified into 4 categories based on their capacity for ionization and number of triiodobenzene rings (Figure 1), as follows:

(1) Ionic monomers: salts comprising 1 negatively charged triiodinated benzene ring, together with a sodium and/or meglumine as a cation. Ionic monomers have the highest osmolality (>1400 mOsm/ $\left./ \mathrm{kg} \mathrm{H}_{2} \mathrm{O}\right)$.

(2) Ionic dimers, which consist of 2 triiodobenzene rings, contain a carboxyl radical, and have low osmolality (600 $\mathrm{mOsm} / \mathrm{kg} \mathrm{H}_{2} \mathrm{O}$ ).

(3) Nonionic monomers, which are triiodinated compounds with hydrophilic hydroxyl groups. Nonionic monomers are second-generation agents and have low osmolality (500-850 $\left.\mathrm{mOsm} / \mathrm{kg} \mathrm{H}_{2} 0\right)$.

(4) Nonionic dimers, which contain 2 nonionic triiodinated benzene rings. Nonionic dimers have the lowest osmolality of all ICM (290 mOsm/kg H 20$)$.

\section{Epidemiology}

The prevalence of allergic reactions to ICM is estimated to be $1: 170000$, that is, $0.05 \%-0.1 \%$ of patients undergoing radiologic studies with ICM $[27,28]$. These percentages are generally higher for ionic ICM $(0.16 \%-12.66 \%)$ than for nonionic ICM $(0.03 \%-3 \%)$ [28-30].

In the past, high-osmolality ICM were associated with a high incidence of immediate reactions [31,32]. In the 1970s, the introduction of nonionic low-osmolality ICM led to a marked decrease in the incidence of these reactions. The prevalence of nonimmediate reactions, however, has increased in the last decade, to the extent that they are now more common than immediate reactions [18]. This observation gives cause for concern, because, unlike immediate reactions, nonimmediate reactions cannot be well controlled by pretreatment with corticosteroids and antihistamines (see below, Treatment). The most frequent culprits ICM for both immediate and nonimmediate reactions are iomeprol and iodixanol [16,33].

Reactions to ICM are usually mild to moderate [34]. Mortality is low, ranging from 1 to 3 per 100000 administrations, for both ionic and nonionic ICM [30,35]. Risk is higher in patients with cardiovascular diseases and in patients with advanced cancer, especially those receiving specific therapies that can potentiate adverse effects (eg, $\beta$-blockers or angiotensin-converting enzyme [ACE] inhibitors). On the other hand, the risk of reactions to ICM in children is lower [36].

The risk factors for hypersensitivity to ICM are not fully established. Table I lists some of the most frequently described risk factors [37-40]. Additional risk factors for immediate reactions that are common to allergic drug reactions include poorly controlled bronchial asthma, concomitant medications (eg, ACE inhibitors, $ß$-blockers, and proton pump inhibitors), rapid administration of the drug, mastocytosis, autoimmune diseases, and viral infections [10,11,38,41-46].

It is noteworthy that, contrary to popular belief, allergy to mollusks, crustaceans, fish, and iodine from other sources is not a risk factor for the development of hypersensitivity reactions to ICM. 
Table 1. Risk Factors for Immediate and Nonimmediate Reactions

Repeated administration of ICM [30]

Using low-osmolality ICM (ionic monomers and dimersiohexol) [16,31-33]

Acute or chronic kidney failure. Serum creatinine $>2 \mathrm{mg} / \mathrm{dL}$ [30]

Other diseases with renovascular involvement, eg, diabetes, myeloma, dehydration

Cardiopulmonary disease

Previous drug allergy

Previous reaction with ICM

Atopy [26]

Female gender $[21,34,35]$

Treatment with IL-2 [18,36,37]

Treatment with ACE inhibitors, $\beta$-blockers, or proton pump inhibitors (immediate reactions) [69]

Abbreviation: ICM, iodinated contrast medium.

\section{Pathogenesis of Hypersensitivity Reactions to ICM}

Similar to hypersensitivity reactions to drugs, reactions to ICM are generally classified into immediate reactions and nonimmediate/delayed reactions $[12,47]$. The panorama of hypersensitivity reactions to ICM is now more complex than initially thought [48].

\section{Immediate Reactions}

The underlying mechanisms of these reactions have been the subject of speculation over the years and were not originally considered to be allergic, but rather anaphylaxis-like or anaphylactoid owing the capacity of former contrast media to induce nonspecific histamine release [49]. However, there is growing evidence that a group of these reactions can be induced by specific immunological mechanisms [14,50,51], a hypothesis that seems increasingly likely with the reporting of cases with immediate positive skin test and basophil activation test results [16].

The various mechanisms involved in immediate nonallergic reactions [52] include the following: (1) the direct membrane effect, possibly related to the osmolality of the ICM solution [53]; (2) activation of the complement system [54]; and (3) direct formation of bradykinin [55].

Several studies support the finding of specific IgE-mediated immunological mechanisms in immediate reactions, and positive skin test results with ICM have been reported in patients who experience severe immediate reactions [14-16]. Some of these patients also react to other ICM to which they had not been previously exposed, probably because the core chemical structure common to ICM is part of the antigenic determinant and thus induces cross-reactivity.
Specific IgE to ioxaglate and ioxithalamate has been determined in the sera of patients who experience immediate reactions to ICM using immunoassay techniques [14,51] and basophil activation tests, as reported for many other drugs [56-58].

Patients who experience hypersensitivity reactions to ICM have increased plasma levels of histamine and tryptase during the reaction [13] that correlate with severity. While these observations do not constitute direct evidence of an IgE-related mechanism, but rather of mast cell activation [14,59], recent studies have also indirectly shown the presence of specific IgE using the basophil activation test $[16,17,53]$.

The finding that some patients react to ICM on their first exposure indicates that a prior sensitization phase is not always necessary. The mechanism may be similar to that involved in anaphylaxis caused by muscle relaxants in individuals who were not previously exposed [60]. The factors that contribute to the high levels of histamine release include genetic variations associated with the metabolism of vasoactive mediators [61].

\section{Nonimmediate Reactions}

According to the penicillin model, nonimmediate reactions can occur as soon as 1-2 hours after administration $[62,63]$. In fact, generalized urticarial reactions mimicking anaphylaxis have been reported with amoxicillin and were first thought to be IgE-like accelerated reactions; however, it was subsequently demonstrated that the mechanism is in fact T cell-dependent [64].

Published studies support the role of a T cell-mediated mechanism in these reactions, as is the case with other drugs. Activation of T cells is observed in both peripheral blood and in the area of skin testing and is detected by the expression of the cutaneous lymphocyte-associated antigen and other chemokine receptors and integrins that interact with their corresponding ligands $[65,66]$.

Several studies of nonimmediate reactions to ICM have shown skin tests to be positive with the ICM involved $[15,60,67,68]$ and with other ICM with similar chemical structures $[15,19]$.

The involvement of $\mathrm{T}$ cells was demonstrated by the presence of perivascular infiltrates of these cells in the dermis of the affected area during the acute phase reaction as well as in the positive skin test area. The lymphocyte proliferation test with the ICM involved in the reaction has also yielded positive results $[19,69,70]$.

Some patients react to ICM upon their first exposure $[15,19]$. One explanation could be that these patients may have been previously sensitized by structurally related molecules.

\section{Clinical Manifestations}

The skin is the most affected organ in both immediate and nonimmediate reactions.

\section{Immediate Reactions}

The most common symptoms are erythema and urticaria with or without angioedema, which appears in more than $70 \%$ of patients [71]. More severe symptoms include dyspnea, 
nausea, vomiting, and hypotension. In the most severe cases, anaphylactic shock and acute coronary syndrome (Kounis syndrome) can occur [72].

The severity scales of Ring and Messmer [73] or Brown [74] can be used to classify the reactions.

\section{Nonimmediate Reactions}

Most reactions occur in the first 3 days after the administration of ICM. They are usually mild to moderate and generally resolve within 7 days $[75,76]$. Maculopapular rash is the most common skin manifestation (30-90\%), followed by delayed urticaria, with or without angioedema (40\%-60\%). Contact dermatitis and fixed drug eruption have also been described. More severe manifestations, such as Stevens-Johnson syndrome, toxic epidermal necrolysis, acute generalized pustulosis, and vasculitis are rare in patients who experience a nonimmediate reaction $[12,33]$.

\section{Nonallergic Reactions}

Clinical manifestations such as heat, facial flushing, dizziness, and nausea can occur immediately after administration of ICM and usually resolve spontaneously. Nonallergic reactions are not suggestive of allergic reactions [77]. They usually occur within the first hour after administration, but can happen after longer intervals and be confused with accelerated reactions; however, these reactions are usually milder.

\section{Diagnosis}

The evaluation of patients with reactions to ICM can be initiated during the acute phase. In immediate reactions, serial measurements of serum tryptase (at the onset of the reaction and 2 and 24 hours later) can help to identify the type of reaction $[59,78]$. A 2-fold increase above baseline levels is suggestive of anaphylaxis (grade of recommendation, C) [79].

In nonimmediate reactions, systemic involvement can be evaluated using a complete blood count and serum chemistry, which enable detection of peripheral blood eosinophilia and evaluation of renal and hepatic function (grade of recommendation, D). Performing a biopsy of the affected skin can provide information about the underlying disease process (grade of recommendation, D).

Once the reaction has resolved, the patient should be assessed using available methods for the diagnosis of reactions to ICM, including clinical history, skin tests, in vitro methods, and controlled administration.

\section{Clinical History}

The clinical history should be taken carefully, as with any adverse drug reaction. Details should include the ICM administered, the interval between administration of the ICM and the onset of symptoms, the symptoms themselves, and the treatment required to control symptoms. The history should also take account of possible previous administration of ICM and subsequent tolerance to this ICM or others (grade of recommendation, D).
Unfortunately, reactions are not often adequately recorded, thus complicating the subsequent allergy workup.

\section{Skin Tests}

Prick and intradermal skin tests should be performed in immediate reactions [80]. The ICM should be used undiluted for skin prick tests and diluted at 1:10 for the intradermal test (grade of recommendation, C) [15]. In the case of severe reactions, intradermal tests should begin with higher dilutions (grade of recommendation, C) [81]. Skin testing should be performed with the ICM involved in the reaction if known. If the result is positive, or if the culprit ICM is unknown, skin testing should be performed with the broadest possible panel of ICM (grade of recommendation, D).

The sensitivity of skin tests for immediate reactions varies from $4.2 \%$ to $73 \%[15,16,77,82]$. Such high variability may be due to the different concentrations used in the studies (undiluted ICM can be associated with false positives), the time between the reaction and the study, the clinical symptoms of the patients included, symptom severity, and the type of ICM (ionic or nonionic) [81]. As occurs with IgE-mediated reactions to drugs, if the time between the reaction and the study is longer, the chance of obtaining a positive result will be lower $[83,84]$. The specificity of intradermal skin tests is estimated at $96.3 \%$ [80]. Although the negative predictive value has been shown to be as high as $96.6 \%$ [67], it decreases to $60 \%$ when controlled exposure tests with ICMs are performed [16].

In nonimmediate reactions, intradermal tests are performed at a 1:10 dilution and patch tests with undiluted ICM. In both cases, the reading should be taken at 48, 72, and 96 hours and occasionally at 7 days (grade of recommendation, C) [15]. Since intradermal testing does not induce false positives in nonimmediate reactions [33], if an intradermal test result is negative at the 1:10 dilution, testing can be repeated with the undiluted ICM (grade of recommendation, C). The intradermal test has higher sensitivity than the patch test $[19,33]$. The negative predictive value of skin tests for nonimmediate reactions is not well established $[35,85]$.

For both immediate and nonimmediate reactions, skin tests should be performed 2-6 months after the reaction; after this period, the number of positive skin test results will be lower (grade of recommendation, D) [15]. Evidence for this statement is rather limited.

\section{In Vitro Methods}

The basophil activation test is used to detect basophil activation markers (CD45, CD18, and CD63) by means of flow cytometry. The basophil activation test is increasingly used with drugs such as ß-lactams [86], quinolones [57], protein pump inhibitors [87], corticosteroids [56], and ICM [16]. Data obtained in preliminary studies of patients who experienced immediate reactions to ICM have shown promising results. Activation was detected in $62.5 \%$ of patients with hypersensitivity to ICM confirmed by positive skin and/or provocation tests (grade of recommendation, D) $[16,82,88]$. This technique is not widely available and needs to be validated in various populations.

The lymphocyte transformation test is based on the ability of $\mathrm{T}$ cells to proliferate upon contact with ICM in 
sensitized patients. Sensitivity was variable in patients who experienced nonimmediate reactions (13-75\%) (grade of recommendation, D) $[25,33]$. This test is not currently used in routine diagnosis. More physiologically relevant tests such as coculture of dendritic cells and lymphocytes may be useful in the future, although further research is required [70].

\section{Drug Provocation Tests}

The drug provocation test (DPT) is considered the gold standard for the diagnosis of drug hypersensitivity reactions. In many instances, particularly in the case of severe reactions, an alternative ICM can be tried in order to verify tolerance or assess reactivity. Such tests can confirm or exclude the diagnosis when there is no other available evidence and can be used to look for an alternative ICM. The ICM to be administered will be chosen depending on the results of skin and in vitro testing, the ICM that induced the reaction (when known), the severity of the reaction, the availability of alternative ICM, and available information about potential ICM cross-reactivity.

The DPT is performed by administering increasing doses of the $\operatorname{ICM}(5,15,30$, and $50 \mathrm{cc})$ at $30-45$-minute intervals $[16,81]$ for immediate reactions and at 1-hour intervals for nonimmediate reactions. In the case of serious nonimmediate reactions, incremental doses must be administered in 2 separate sessions with a gap of at least 1 week between sessions. The dose must be increased gradually: 5,10 , and $15 \mathrm{cc}$ on the first day (cumulative total of $30 \mathrm{cc}$ ) and 20,30, and $50 \mathrm{cc}$ on the second day, a week later (cumulative total of $100 \mathrm{cc}$ ) (grade of recommendation, C) [19].

Intravenous administration of ICM can cause acute kidney damage, which is usually reversible. Its incidence is variable, ranging from $0 \%$ to $55 \%$, and is higher in the presence of associated risk factors (underlying renal disease with serum creatinine $>1.5 \mathrm{mg} / \mathrm{dL}$, diabetic nephropathy, advanced heart failure, or other causes involving reduced renal perfusion [eg, hypovolemia, anemia, percutaneous coronary intervention, and multiple myeloma]). The osmolality and amount of ICM given are also important, with higher-osmolality ICM and doses higher than $140 \mathrm{~mL}$, or repeated doses within 48 hours, more likely to lead to damage. The concomitant use of diuretics, metformin, or nonsteroidal anti-inflammatory drugs is another factor to consider. We suggest that low-osmolality or isosmolar ICMs should be given in patients who experience kidney damage (grade of recommendation, C) [50]. Furthermore, depending on the individual risk, it is recommended to administer oral serum bicarbonate, oral $\mathrm{N}$-acetylcysteine, and intravenous saline solution $(0.9 \%)$ according to different published regimens before and after ICM as prophylaxis against renal damage [89].

\section{Cross-reactivity}

Cross-reactivity between ICM is less common in immediate reactions [33] and is related to chemical structure [90]. The association most frequently detected is between iodixanol, iohexol, iopentol, ioversol, and iomeprol. This is particularly relevant between iodixanol and iohexol monomers. Other ICM such as ioxaglate, iopamidol, iobitridol, and iopromide have limited cross-reactivity $[15,19]$ (Table 2).
Table 2. Cross-reactivity of ICMs

\begin{tabular}{lll}
\hline $\begin{array}{l}\text { Strong } \\
\text { Association }\end{array}$ & $\begin{array}{l}\text { Frequent } \\
\text { Association }\end{array}$ & $\begin{array}{l}\text { Limited } \\
\text { Association }\end{array}$ \\
\hline Iodixanol & Iodixanol & Ioxaglate \\
Iohexol & Iohexol & Iopamidol \\
& Iopentol & Iobitridol \\
& Ioversol & Iopromide \\
& Iomeprol & \\
\hline
\end{tabular}

Given the different patterns of cross-reactivity, skin tests based on as wide a battery of ICM as possible are recommended (grade of recommendation, D) [91]. However, since a negative skin test result to an alternative ICM does not necessarily mean the patient will not respond to its administration, controlled administration is also recommended.

\section{Algorithm}

The recommended diagnostic algorithm is provided in Figure 2. Nonhypersensitivity reactions do not require an allergy study. Suggestive hypersensitivity reactions can be immediate or nonimmediate.

In the case of immediate reactions, the first approach is to perform skin prick tests with a battery of ICM and take a reading 15-20 minutes after application. If the results are negative, an intradermal test should be performed. In the case of a negative skin test result for the culprit ICM, a DPT should be performed (although not if the patient had previously experienced a severe reaction). If skin testing gives a positive result for the culprit ICM, a DPT should be performed with an alternative ICM that gave a negative skin test result in order to identify a safe alternative.

Nonimmediate reactions to intradermal and patch tests with delayed readings should be performed with a battery of ICM. If the results are positive, alternatives should be sought using the procedure described for immediate reactions. In the case of negative skin test results, the approach will depend on whether the reaction was mild or moderate to severe. In the first case, the DPT will be performed with the culprit ICM on a single day. In the second case, the DPT will be performed with an alternative ICM over 2 days. In patients with severe medical reactions such as Stevens-Johnson syndrome, toxic epidermal necrolysis, drug reaction with eosinophilia and systemic symptoms, or acute generalized exanthematic pustulosis, as well as in patients with organ-specific reactions (eg, ICM-induced hepatitis), readministration of the culprit ICM is absolutely contraindicated, even when the result of the skin test is negative. In these situations, the administration of an alternative ICM should only be considered if absolutely necessary, and a careful analysis of the potential risks and benefits should be performed.

\section{Treatment}

Early recognition of a reaction is essential for proper treatment. This should not prove difficult if the reaction 


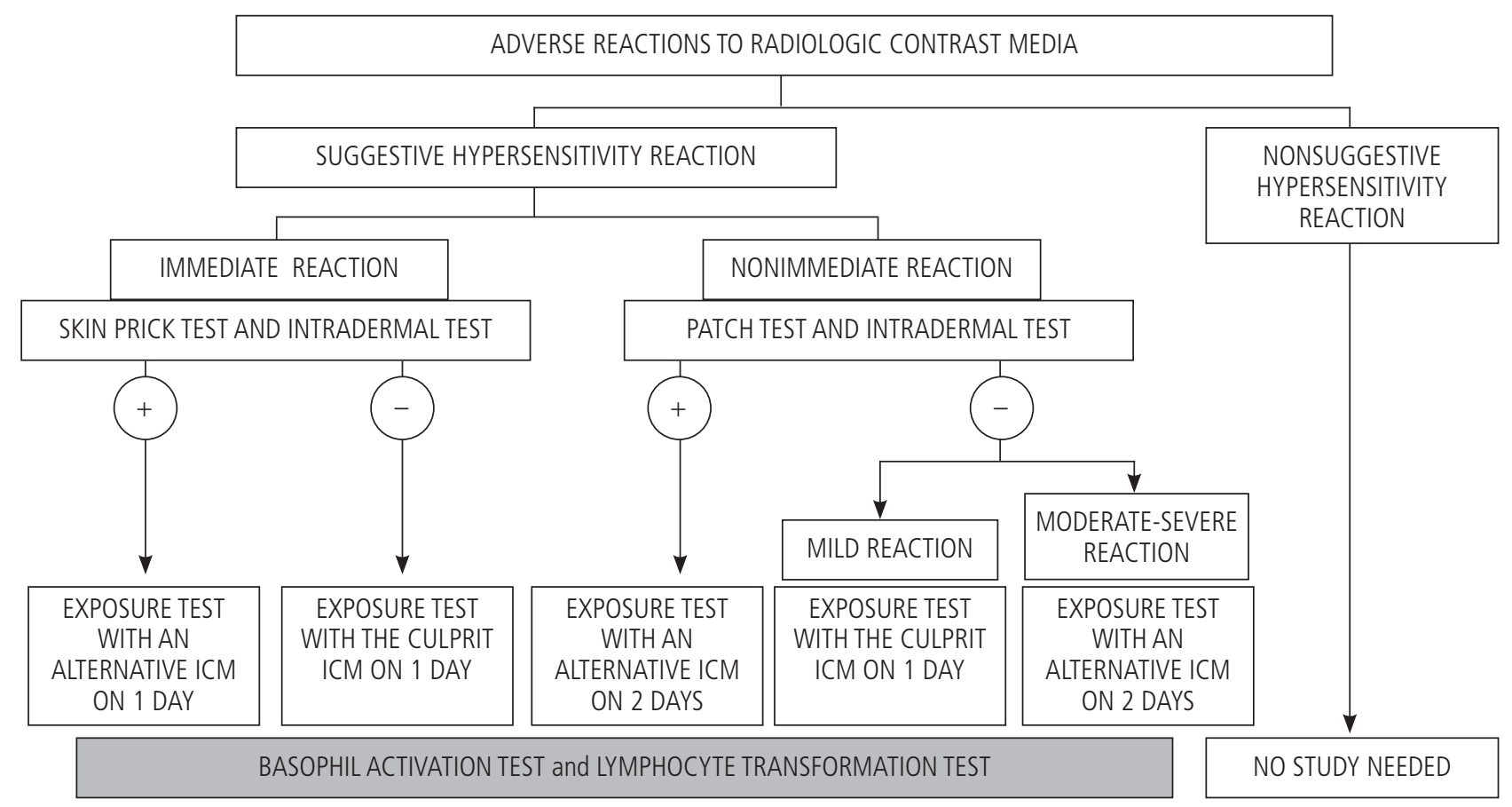

Figure 2. Diagnostic algorithm. If the culprit ICM is unknown, intravenous exposure will be performed with one of the commonly used ICMs that gave a negative skin test result, as long as the severity of the reaction or the clinical situation of the patient does not contraindicate readministration.

is reported in the setting where it occurs, although it is rather uncommon if the reaction occurs 24-48 hours after administration of the ICM. Therefore, following a radiological examination with ICM, the patient should remain under observation for at least 30 minutes (grade of recommendation, C) [92]. It is essential that patients undergoing treatment with ICM be given instructions on how to proceed in a nonimmediate reaction.

First-line drugs for treatment of anaphylaxis must always be available, as should the equipment and trained personnel required for its management, including potential cardiac arrest. If symptoms appear, the ICM infusion should be interrupted immediately, and an appropriate treatment administered [27,93]. Some authors propose that mild reactions such as itching and hives are usually self-limiting and thus do not require treatment [93], although they are usually treated with anti- $\mathrm{H}_{1}$ blockers (grade of recommendation, D) [27]. It is always necessary to maintain venous patency, and the patient should be observed carefully for possible progression to more severe symptoms. Treatment of systemic reactions is administered according to the GALAXIA guide for anaphylaxis [79]. Mild and moderate bronchospasm should be treated with oxygen and inhaled $\beta_{2}$-agonists (grade of recommendation, B) [93]. Anaphylactic reactions require treatment with epinephrine (grade of recommendation, A) [93].

The value of premedication is rather controversial and may induce a false sense of security, especially when it is administered systematically without a prior allergy study (grade of recommendation, D). It has only been shown to reduce the occurrence of mild immediate reactions and has not been demonstrated to be useful for immediate moderate to severe and nonimmediate reactions [46,94,95].

Guidelines from ENDA in 2005 recommended the use of premedication when administering an alternative ICM that gave a negative skin test result. However, following the results of several studies that evaluated controlled challenge [16,19,81], the use of premedication is being questioned (grade of recommendation, D) (see diagnostic algorithm, Figure 2).

The most common premedication protocol used is oral prednisone $50 \mathrm{mg}$ or intravenous methylprednisolone $40 \mathrm{mg}$ administered 13, 7, and 1 hour before injection of ICM, with intravenous dexchlorpheniramine $5 \mathrm{mg}$ also given 1 hour before. If an urgent radiological examination with ICM is needed, intravenous hydrocortisone $200 \mathrm{mg}$ and intravenous dexchlorpheniramine $5 \mathrm{mg}$ should be administered 1 hour before injection of ICM (grade of recommendation, D) [71].

\section{Reactions to Other Radiologic Contrast Media}

The most frequently used noniodinated radiologic contrast media are barium and paramagnetic agents.

\section{Barium Contrast Media}

Barium contrast agents contain barium sulfate and are used to visualize areas of the digestive tract [96]. They are administered orally or rectally. The most common adverse reactions are mild and nonallergic and include diarrhea, constipation, nausea, and vomiting. 
The prevalence of allergic reactions is less than 2 per million [96,97], although this frequency is increasing [98]. Barium sulfate is inert and nonantigenic and is generally not absorbed by the intestinal tract. However, some additives present in barium formulations such as carboxymethylcellulose and methylparaben are absorbed and might be responsible for adverse reactions [99-101]. In addition, drugs such as glucagon, which are used to reduce discomfort during scans with barium sulfate, have also been implicated in allergic reactions [102].

\section{Contrast Media Used in MRI}

Most paramagnetic contrast media used in MRI are gadolinium chelates or complexes [103,104]. These molecules are classified depending on their net charge as ionic or nonionic and on their structure as linear or macrocyclic (Figure 3).

Immediate hypersensitivity reactions to gadolinium derivatives are the most frequently described, with an incidence of $0.07 \%$ in adults and $0.04 \%$ in children $[103,104]$. Reactions have been reported more frequently for abdominal explorations $(0.01 \%)$ than for explorations of the brain $(0.005 \%)$ or spine $(0.003 \%)$ [105] and after administration of dimeglumine gadobenate and gadoteridol [104-107].

The risk factors for reactions to paramagnetic contrast media are very similar to those described for ICM. The main risk is that of recurrence, which affects $30 \%$ of patients who have already experienced a reaction. Female gender and a history of rhinitis or asthma, food allergy, and hypersensitivity reactions to other drugs have also been associated with an increased risk of reaction [104].

The symptoms described with gadolinium chelates are very similar to those of immediate reactions to ICM and are mostly mild [104,105]. The most common clinical manifestation is urticaria (50-90\% of cases). Anaphylactic reactions are rare, with an incidence of $0.004 \%$ to $0.01 \%$ [20,104]. To our knowledge, nonimmediate hypersensitivity reactions to gadolinium chelates have not been described to date, although the possibility of such a reaction occurring cannot be ruled out.

The pathophysiological mechanisms underlying these reactions are not well known. Involvement of specific IgE has been suggested, based on positive skin test results in patients with anaphylactic reactions to MRI contrast media [20-23].

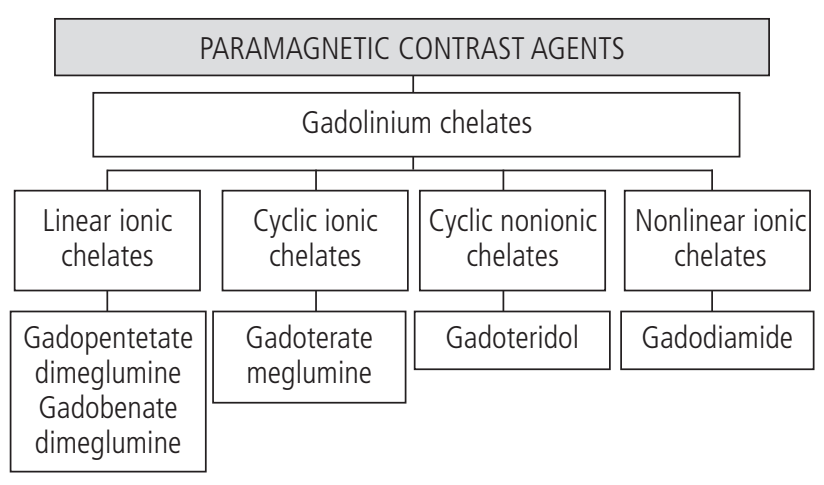

Figure 3. Classification of paramagnetic contrast media.
Several cases of anaphylaxis with gadolinium chelates (meglumine gadoterate, gadoteridol, and dimeglumine gadopentetate) have been reported [104,105,108]. In some cases, positive results were detected using undiluted contrast for skin prick tests and dilutions of $1: 1000$ to $1: 10$ for intradermal tests (grade of recommendation, D) [21$23,109,110]$. Cross-reactivity between gadolinium chelates is still unclear $[22,23,111]$, although it appears not to exist between macrocyclic and linear substances. In the case of immediate hypersensitivity reactions, it would be advisable to use gadolinium chelates as an alternative to the culprit, preferably with a different molecular structure (grade of recommendation, D). Skin testing should also be performed (grade of recommendation, D) [23,112].

\section{Comments and Further Research}

Contrast media are increasingly used worldwide, with millions of explorations being performed every day. Therefore, although these reactions are rare, they occur regularly and are often severe and even life-threatening [16].

The search for alternative ICM is critical, given that many patients require ICM-based procedures for diagnosis and disease monitoring. Therefore, we must distinguish between the different types of reactions where immunological mechanisms are involved (ie, nonallergic and true allergic hypersensitivity reactions) [52]. ICM can cause a wide variety of clinical conditions that are induced by different mechanisms and vary in terms of severity, the diagnostic procedures involved, and the choice of alternatives [113].

The efforts made by the ENDA and EAACI groups are key to progress in this area and will lead to major clinical benefits $[18,114]$.

\section{Acknowledgments}

We thank Professors Miguel Blanca and Ignacio Dávila for their in-depth review of our manuscript.

\section{Funding}

The authors declare that no funding was received for the present study.

\section{Conflicts of Interest}

The authors declare that they have no conflicts of interest.

\section{References}

1. Harbour R, Miller J.A new system for grading recommendations in evidence based guidelines. BMJ. 2001;323:334-6.

2. Strain WH, French JD, Jones GE. lodinated organic compounds as contrast media for radiographic diagnoses; escape of pantopaque from the intracranial subarachnoid space of dogs. Radiology. 1946;47:47-50.

3. Chalecke WE, Jones GE, Miller LL, Steinhausen TB, Strain WH. lodinated organic compounds as contrast media for 
radiographic diagnoses; experimental studies on emulsions of ethyl iodophenylundecylate (pantopaque). Radiology. 1947;49:131-6.

4. Jones GE, Grohowski AL, Robertson HD, Ramsey GH, Schilling JA, Strain WH. lodinated organic compounds as contrast media for radiographic diagnoses; experimental studies on the visualization of the biliary tract. Radiology. 1948;51:225-36.

5. Shehadi WH. Clinical problems and toxicity of contrast agents. AJR Am J Roentgenol. 1966;97:762-71.

6. Knoefel PK. Radiopaque Diagnostic Agents. Annu Rev Pharmacol Toxicol. 1965;5:321-34.

7. Singh J, Daftary A. lodinated contrast media and their adverse reactions. J Nucl Med Technol. 2008;36:69-74; quiz 6-7.

8. Christiansen C. X-ray contrast media--an overview. Toxicology. 2005;209:185-7.

9. Brockow K. Immediate and delayed reactions to radiocontrast media: is there an allergic mechanism? Immunol Allergy Clin North Am. 2009;29:453-68.

10. Bettmann MA, Heeren T, Greenfield A, Goudey C. Adverse events with radiographic contrast agents: results of the SCVIR Contrast Agent Registry. Radiology. 1997;203:611-20.

11. Ansell G, Tweedie MC, West CR, Evans P, Couch L. The current status of reactions to intravenous contrast media. Invest Radiol. 1980;15(Suppl):S32-9.

12. Brockow K, Christiansen C, Kanny G, Clément O, Barbaud A, Bircher A, Dewachter P, Guéant JL, Rodriguez Guéant RM, Mouton-Faivre C, Ring J, Romano A, Sainte-Laudy J, Demoly $\mathrm{P}$, Pichler WJ. Management of hypersensitivity reactions to iodinated contrast media. Allergy. 2005;60:150-8.

13. Schwartz LB, Metcalfe DD, Miller JS, Earl H, Sullivan T. Tryptase levels as an indicator of mast-cell activation in systemic anaphylaxis and mastocytosis. N Engl J Med. 1987;316:16226.

14. Laroche D, Aimone-Gastin I, Dubois $F$, Huet $H$, Gérard $P$, Vergnaud MC, Mouton-Faivre C, Guéant JL, Laxenaire MC, Bricard $\mathrm{H}$. Mechanisms of severe, immediate reactions to iodinated contrast material. Radiology. 1998;209:183-90.

15. Brockow K, Romano A, Aberer W, Bircher AJ, Barbaud A, Bonadonna P, Faria E, Kanny G, Lerch M, Pichler WJ, Ring J, Rodrigues Cernadas J, Tomaz E, Demoly P, Christiansen C. Skin testing in patients with hypersensitivity reactions to iodinated contrast media - a European multicenter study. Allergy. 2009;64:234-41.

16. Salas M, Gomez F, Fernandez TD, Doña I, Aranda A, Ariza A, Blanca-López N, Mayorga C, Blanca M, Torres MJ. Diagnosis of immediate hypersensitivity reactions to radiocontrast media. Allergy. 2013;68:1203-6.

17. Pinnobphun P, Buranapraditkun S, Kampitak T, Hirankarn $N$, Klaewsongkram J. The diagnostic value of basophil activation test in patients with an immediate hypersensitivity reaction to radiocontrast media. Ann Allergy Asthma Immunol. 2011;106:387-93.

18. Doña I, Barrionuevo E, Blanca-Lopez N, Torres MJ, Fernandez TD, Mayorga C, Canto G, Blanca M. Trends in hypersensitivity drug reactions: more drugs, more response patterns, more heterogeneity. J Investig Allergol Clin Immunol. 2014;24:14353; quiz 1 p following 53.

19. Torres MJ1, Gomez F, Doña I, Rosado A, Mayorga C, Garcia I, Blanca-Lopez N, Canto G, Blanca M. Diagnostic evaluation of patients with nonimmediate cutaneous hypersensitivity reactions to iodinated contrast media. Allergy. 2012;67:92935.

20. Li A, Wong CS, Wong MK, Lee CM, Au Yeung MC. Acute adverse reactions to magnetic resonance contrast media-gadolinium chelates. Br J Radiol. 2006;79:368-71.

21. Schiavino D, Murzilli F, Del Ninno M, Buonomo A, Roncallo C, Pollastrini E, De Pasquale T, Lombardo C, Nucera E, Patriarca G. Demonstration of an IgE-mediated immunological pathogenesis of a severe adverse reaction to gadopentetate dimeglumine. J Investig Allergol Clin Immunol. 2003;13:140-2.

22. Hasdenteufel F, Luyasu S, Renaudin JM, Paquay JL, Carbutti G, Beaudouin E, Moneret-Vautrin DA, Kanny G. Anaphylactic shock after first exposure to gadoterate meglumine: two case reports documented by positive allergy assessment. J Allergy Clin Immunol. 2008;121:527-8.

23. Galera C, Pur Ozygit L, Cavigioli S, Bousquet PJ, Demoly P. Gadoteridol-induced anaphylaxis - not a class allergy. Allergy. $2010 ; 65: 132-4$.

24. García Mónaco RP, Ocantos JA. Medios de contraste radiológicos / lo que un médico no puede dejar de conocer. http://www.edicionesjournal.com2011.

25. Martí-Bonmatí L. Medios de contraste en Radiología. Colección: MONOGRAFÍAS SERAM. Edición: 1 (10 de diciembre de 2007). Sociedad Española de Radiología Médica (SERAM). http://desarrollo.proengsoft.com/seram/contents/ documentos/2007.

26. Ramírez Ribelles C, Sánchez Fuster MA, Pamies Guilabert J. Contrastes yodados de utilización en Radiología. Radiologia. 2014;56(Supl. 1):12-20.

27. Hong SC, ST. Immediate hypersensitivity reactions to radiocontrast media: Clinical manifestations, diagnosis, and treatment. www.UptoDate.com (Accessed December 2014).

28. Newmark JL, Mehra A, Singla AK. Radiocontrast media allergic reactions and interventional pain practice--a review. Pain Physician. 2012;15:E665-75.

29. International Collaborative Study of Severe A. Risk of anaphylaxis in a hospital population in relation to the use of various drugs: an international study. Pharmacoepidemiol Drug Saf. 2003;12:195-202.

30. Cochran ST. Anaphylactoid reactions to radiocontrast media. Curr Allergy Asthma Rep. 2005;5:28-31.

31. Wolf GL, Arenson RL, Cross AP. A prospective trial of ionic vs nonionic contrast agents in routine clinical practice: comparison of adverse effects. AJR Am J Roentgenol. 1989;152:939-44.

32. Palmer FJ. The RACR survey of intravenous contrast media reactions. Final report. Australas Radiol. 1988;32:426-8.

33. Gomez E, Ariza A, Blanca-Lopez N, Torres MJ. Nonimmediate hypersensitivity reactions to iodinated contrast media. Curr Opin Allergy Clin Immunol. 2013;13:345-53.

34. Wang CL, Cohan RH, Ellis JH, Caoili EM, Wang G, Francis IR. Frequency, outcome, and appropriateness of treatment of nonionic iodinated contrast media reactions. AJR Am J Roentgenol. 2008;191:409-15.

35. Pradubpongsa P, Dhana N, Jongjarearnprasert K, Janpanich S, Thongngarm T. Adverse reactions to iodinated contrast media: prevalence, risk factors and outcome-the results of a 3-year period. Asian Pac J Allergy Immunol. 2013;31:299-306. 
36. Gaca AM, Frush DP, Hohenhaus SM, Luo X, Ancarana A, Pickles A, Frush KS. Enhancing pediatric safety: using simulation to assess radiology resident preparedness for anaphylaxis from intravenous contrast media. Radiology. 2007;245:236-44.

37. Hosoya T, Yamaguchi K, Akutsu T, Mitsuhashi Y, Kondo S, Sugai Y, Adachi M. Delayed adverse reactions to iodinated contrast media and their risk factors. Radiat Med. 2000;18:39-45.

38. Choyke PL, Miller DL, Lotze MT, Whiteis JM, Ebbitt B, Rosenberg SA. Delayed reactions to contrast media after interleukin-2 immunotherapy. Radiology. 1992;183:111-4.

39. Yoshikawa $\mathrm{H}$. Late adverse reactions to nonionic contrast media. Radiology. 1992;183:737-40.

40. Aoki Y, Takemura T. Allergies correlated to adverse reactions induced by non-ionic monomeric and ionic dimeric contrast media for contrast enhanced CT examination. Nihon Hoshasen Gijutsu Gakkai Zasshi. 2002;58:1245-51.

41. Kobayashi D, Takahashi O, Ueda T, Arioka H, Akaishi Y, Fukui T. Asthma severity is a risk factor for acute hypersensitivity reactions to contrast agents: a large-scale cohort study. Chest. 2012;141:1367-8.

42. Lang DM, Alpern MB, Visintainer PF, Smith ST. Elevated risk of anaphylactoid reaction from radiographic contrast media is associated with both beta-blocker exposure and cardiovascular disorders. Arch Intern Med. 1993;153:203340.

43. Federle MP, Willis $L L$, Swanson DP. Ionic versus nonionic contrast media: a prospective study of the effect of rapid bolus injection on nausea and anaphylactoid reactions. J Comput Assist Tomogr. 1998;22:341-5.

44. Pichler WJ, Yawalkar N, Britschgi M, Depta J, Strasser I, Schmid S, Kuechler P, Naisbitt D. Cellular and molecular pathophysiology of cutaneous drug reactions. Am J Clin Dermatol. 2002;3:229-38.

45. Pichler WJ, Yawalkar N. Allergic reactions to drugs: involvement of T cells. Thorax. 2000;55 Suppl 2:S61-5.

46. Ramírez $\mathrm{E}$, Tong HY, Fiandor A, Martín-Hervás C, Rivero D, Oñate M, Rueda C, Cabañas R, Moro M, Tapia M, Fernández A, Morón S, Herrero A, Garzón G, Quirce S, Frías J. Hypersensitivity reactions to contrast media injections: a nested case-control study. Ann Allergy Asthma Immunol. 2014;113:488-9 e5.

47. Brockow K. Contrast media hypersensitivity--scope of the problem. Toxicology. 2005;209:189-92.

48. Doña I, Blanca-López N, Torres MJ, García-Campos J, GarcíaNúñez I, Gómez F, Salas M, Rondón C, Canto MG, Blanca M. Drug hypersensitivity reactions: response patterns, drug involved, and temporal variations in a large series of patients. J Investig Allergol Clin Immunol. 2012;22:363-71.

49. Johansson SG, Hourihane JO, Bousquet J, Bruijnzeel-Koomen C, Dreborg S, Haahtela T, Kowalski ML, Mygind N, Ring J, van Cauwenberge $P$, van Hage-Hamsten $M$, Wüthrich $B$. A revised nomenclature for allergy. An EAACI position statement from the EAACI nomenclature task force. Allergy. 2001;56:813-24.

50. Goksel O, Aydın O, Atasoy C, Akyar S, Demirel YS, Misirligil Z, Bavbek S. Hypersensitivity reactions to contrast media: prevalence, risk factors and the role of skin tests in diagnosis--a cross-sectional survey. Int Arch Allergy Immunol. 2011;155:297-305

51. Mita H, Tadokoro K, Akiyama K. Detection of IgE antibody to a radiocontrast medium. Allergy. 199;53:1133-40.
52. Johansson SG, Bieber T, Dahl R, Friedmann PS, Lanier BQ, Lockey RF, Motala C, Ortega Martell JA, Platts-Mills TA, Ring J, Thien F, Van Cauwenberge P, Williams HC. Revised nomenclature for allergy for global use: Report of the Nomenclature Review Committee of the World Allergy Organization, October 2003. J Allergy Clin Immunol. 2004;113:832-6.

53. Brockow K, Ring J. Anaphylaxis to radiographic contrast media. Curr Opin Allergy Clin Immunol. 2011;11:326-31.

54. Szebeni J. Hypersensitivity reactions to radiocontrast media: the role of complement activation. Curr Allergy Asthma Rep. 2004;4:25-30.

55. Ring J, Arroyave CM, Frizler MJ, Tan EM. In vitro histamine and serotonin release by radiographic contrast media (RCM). Complement-dependent and -independent release reaction and changes in ultrastructure of human blood cells. Clin Exp Immunol. 1978;32:105-18.

56. Aranda A, Mayorga C, Ariza A, Doña I, Blanca-Lopez N, Canto G, Blanca M, Torres MJ. IgE-mediated hypersensitivity reactions to methylprednisolone. Allergy. 2010;65:1376-80.

57. Aranda A, Mayorga C, Ariza A, Doña I, Rosado A, BlancaLopez N, Andreu I, Torres MJ. In vitro evaluation of IgEmediated hypersensitivity reactions to quinolones. Allergy. $2011 ; 66: 247-54$.

58. Torres MJ, Ariza A, Mayorga C, Doña I, Blanca-Lopez $\mathrm{N}$, Rondon C, Blanca M. Clavulanic acid can be the component in amoxicillin-clavulanic acid responsible for immediate hypersensitivity reactions. J Allergy Clin Immunol. 2010;125:502-5 e2.

59. Fernandez J, Blanca M, Moreno F, Garcia J, Segurado E, del Cano A, Aguilar F. Role of tryptase, eosinophil cationic protein and histamine in immediate allergic reactions to drugs. Int Arch Allergy Immunol. 1995;107:160-2.

60. Gall H, Pillekamp H, Peter RU. Late-type allergy to the X-ray contrast medium Solutrast (iopamidol). Contact Dermatitis. 1999;40:248-50.

61. Agúndez JA, Ayuso P, Cornejo-García JA, Blanca M, Torres MJ, Doña I, Salas M, Blanca-López N, Canto G, Rondon C, Campo P, Laguna JJ, Fernández J, Martínez C, García-Martín E. The diamine oxidase gene is associated with hypersensitivity response to non-steroidal anti-inflammatory drugs. PloS One. 2012;7:e47571.

62. Terrados S, Blanca M, Garcia J, Vega J, Torres MJ, Carmona MJ, Miranda A, Moya M, Juarez C, Fernandez J. Nonimmediate reactions to betalactams: prevalence and role of the different penicillins. Allergy. 1995; 50:563-7.

63. Torres MJ, Blanca M. The complex clinical picture of beta-lactam hypersensitivity: penicillins, cephalosporins, monobactams, carbapenems, and clavams. Med Clin North Am. 2010;94:805-20, xii.

64. Gómez E, Blanca-Lopez N, Salas M, Canto G, Campo P, Torres MJ, Mayorga C, Blanca M. Induction of accelerated reactions to amoxicillin by T-cell effector mechanisms. Ann Allergy Asthma Immunol. 2013;110:267-73.

65. Blanca M, Posadas S, Torres MJ, Leyva L, Mayorga C, Gonzalez L, Juarez C, Fernández J, Santamaria LF. Expression of the skin-homing receptor in peripheral blood lymphocytes from subjects with nonimmediate cutaneous allergic drug reactions. Allergy. 2000;55:998-1004.

66. Mayorga C, Pena RR, Blanca-Lopez N, Lopez S, Martin E, Torres MJ. Monitoring the acute phase response in non-immediate 
allergic drug reactions. Curr Opin Allergy Clin Immunol. 2006:6:249-57.

67. Caimmi S, Benyahia B, Suau D, Bousquet-Rouanet L, Caimmi $D$, Bousquet PJ, Demoly P. Clinical value of negative skin tests to iodinated contrast media. Clin Exp Allergy. 2010;40:80510.

68. Kvedariene $V$, Martins $P$, Rouanet L, Demoly P. Diagnosis of iodinated contrast media hypersensitivity: results of a 6 -year period. Clin Exp Allergy. 2006;36:1072-7.

69. Torres MJ, Mayorga C, Cornejo-Garcia JA, Lopez S, Chaves P, Rondon C, Fernandez T, Blanca M. Monitoring non-immediate allergic reactions to iodine contrast media. Clin Exp Immunol. 2008;152:233-8.

70. Antunez C, Barbaud A, Gomez E, Audonnet S, Lopez S, GuéantRodriguez RM, Aimone-Gastin I, Gomez F, Blanca M, Guéant $J$ L. Recognition of iodixanol by dendritic cells increases the cellular response in delayed allergic reactions to contrast media. Clin Exp Allergy. 2011;41:657-64.

71. Gracia Bara MT HLT, Iriartes Sotés P, Cruz Granados MS, Infante Herrero $S$. Reacciones alérgicas inducidas por fármacos poco habituales (I): de masa molecular baja o inorgánicos. In: I PAD, editor. Tratado de Alergología: Ergon; 2007. p. 1531-56.

72. Bohm I. Kounis syndrome in a patient with allergy to iodinated contrast media. Int J Cardiol. 2011;151:102-3.

73. Ring J, Messmer K. Incidence and severity of anaphylactoid reactions to colloid volume substitutes. Lancet. 1977;1(8009):466-9.

74. Brown SG. Clinical features and severity grading of anaphylaxis. J Allergy Clin Immunol. 2004;114:371-6.

75. Webb JA, Stacul F, Thomsen HS, Morcos SK, Members Of The Contrast Media Safety Committee Of The European Society Of Urogenital Radiology. Late adverse reactions to intravascular iodinated contrast media. Eur Radiol. 2003;13:181-4.

76. Bellin MF, Stacul F, Webb JA, Thomsen HS, Morcos SK, Almén T, Aspelin P, Clement O, Heinz-Peer G, Reimer P, van der Molen

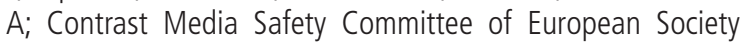
of Urogenital Radiology (ESUR). Late adverse reactions to intravascular iodine based contrast media: an update. Eur Radiol. 2011;21:2305-10.

77. Trcka J, Schmidt C, Seitz CS, Brocker EB, Gross GE, Trautmann A. Anaphylaxis to iodinated contrast material: nonallergic hypersensitivity or lgE-mediated allergy? AJR Am J Roentgenol. 2008;190:666-70.

78. Gomez E, Torres MJ, Mayorga C, Blanca M. Immunologic evaluation of drug allergy. Allergy Asthma Immunol Res. 2012;4:251-63.

79. Cardona Dahl V, Cabañes Higuero N, Montserrat Fernández Rivas M, Freijó Martín C, Guardia Martínez P, de la Hoz Caballer B, Lobera Labairu T, Nevot Falco S, Pascual Marcos C, Vega Castro A, Villarroel González P, Chivato Pérez T. Grupo de trabajo de la Guía GALAXIA de actuación en anafilaxia. [Guideline for the management of anaphylaxis]. Med Clin (Barc). 2011;136:349-55.

80. Brockow K, Garvey LH, Aberer W, Atanaskovic-Markovic M, Barbaud A, Bilo MB, Bircher A, Blanca M, Bonadonna B, Campi P, Castro E, Cernadas JR, Chiriac AM, Demoly P, Grosber M, Gooi J, Lombardo C, Mertes PM, Mosbech H, Nasser S, Pagani M, Ring J, Romano A, Scherer K, Schnyder B, Testi S, Torres M, Trautmann A, Terreehorst I; ENDA/EAACI Drug Allergy Interest
Group. Skin test concentrations for systemically administered drugs -- an ENDA/EAACI Drug Allergy Interest Group position paper. Allergy. 2013;68:702-12.

81. Prieto-García A, Tomás $M$, Pineda $R$, Tornero $P$, Herrero $T$, Fuentes $V$, Zapatero L, de Barrio M. Skin test-positive immediate hypersensitivity reaction to iodinated contrast media: the role of controlled challenge testing. J Investig Allergol Clin Immunol. 2013;23:183-9.

82. Dewachter P, Mouton-Faivre C, Felden F. Allergy and contrast media. Allergy. 2001;56:250-1.

83. Fernández TD, Torres MJ, Blanca-López N, Rodríguez-Bada JL, Gomez E, Canto G, Mayorga C, Blanca M. Negativization rates of IgE radioimmunoassay and basophil activation test in immediate reactions to penicillins. Allergy. 2009;64:242-8.

84. Gómez E, Blanca-Lopez N, Torres MJ, Requena G, Rondon C, Canto G, Blanca M, Mayorga C. Immunoglobulin E-mediated immediate allergic reactions to dipyrone: value of basophil activation test in the identification of patients. Clin Exp Allergy. 2009;39:1217-24.

85. Hasdenteufel F, Waton J, Cordebar V, Studer M, Collignon O, Luyasu S, Beaudouin E, Renaudin JM, Morisset M, Kanny G, Barbaud A. Delayed hypersensitivity reactions caused by iodixanol: an assessment of cross-reactivity in 22 patients. J Allergy Clin Immunol. 2011;128:1356-7.

86. Torres MJ, Padial A, Mayorga C, Fernandez T, Sanchez-Sabate E, Cornejo-Garcia JA, Antunez C, Blanca M. The diagnostic interpretation of basophil activation test in immediate allergic reactions to betalactams. Clin Exp Allergy. 2004;34(11):1768-75.

87. Pérez-Ezquerra PR, Morillas LS, Martínez JJ, Fernández GD, Gomez-Tembleque Mdel P, Alvarez AS, Sanz ML. Anaphylaxis to omeprazole. Cross-reactivity with the other proton pump inhibitors. Allergol Immunopathol (Madr). 2011;39:54.

88. Torres MJ. Basophil activation test (BAT) in the diagnosis of immediate hypersensitivity reactions to radiocontrast media-reply. Allergy. 2013;68:1628-9.

89. Rudnick MR, Goldfarb S, Tumlin J. Contrast-induced nephropathy: is the picture any clearer? Clin J Am Soc Nephrol. 2008:3:261-2.

90. Seitz CS, Pfeuffer P, Raith P, Brocker EB, Trautmann A. Radiocontrast media-associated exanthema: identification of cross-reactivity and tolerability by allergologic testing. Eur J Radiol. 2009;72:167-71.

91. Bavbek S, Sözener ZC, Aydin Ö, Özdemir SK, Gül Ü, Heper AO. First case report of acute generalized exanthematous pustulosis due to intravenous iopromide. J Investig Allergol Clin Immunol. 2014;24:56-71.

92. Christiansen C. Hypersensitivity Reactions to lodinated Contrast Media: An Update. In: WJ Pilcher, editor. Drug Hypersensitivity: Karger; 2007. p. 233-41.

93. Bottinor W, Polkampally $P$, Jovin I. Adverse reactions to iodinated contrast media. Int J Angiol. 2013;22:149-54.

94. Schopp JG, lyer RS, Wang CL, Petscavage JM, Paladin AM, Bush WH, Dighe MK. Allergic reactions to iodinated contrast media: premedication considerations for patients at risk. Emerg Radiol. 2013;20:299-306.

95. Kolbe AB, Hartman RP, Hoskin TL, Carter RE, Maddox DE, Hunt $\mathrm{CH}$, Hesley GK. Premedication of patients for prior urticarial reaction to iodinated contrast medium. Abdom Imaging. 2014;39:432-7. 
96. Janower ML. Hypersensitivity reactions after barium studies of the upper and lower gastrointestinal tract. Radiology. 1986;161:139-40.

97. Gelfand DW, Sowers JC, DePonte KA, Sumner TE, Ott DJ. Anaphylactic and allergic reactions during double-contrast studies: is glucagon or barium suspension the allergen? AJR Am J Roentgenol. 1985;144:405-6.

98. Stringer DA, Hassall E, Ferguson AC, Cairns R, Nadel $H$, Sargent M. Hypersensitivity reaction to single contrast barium meal studies in children. Pediatr Radiol. 1993;23:587-8.

99. Schwartz EE, Glick SN, Foggs MB, Silverstein GS. Hypersensitivity reactions after barium enema examination. AJR Am J Roentgenol. 1984;143:103-4.

100. Muroi N, Nishibori M, Fujii T, Yamagata M, Hosoi S, Nakaya N, Saeki K, Henmi K. Anaphylaxis from the carboxymethylcellulose component of barium sulfate suspension. N Engl J Med. 1997;337:1275-7.

101. Dumond P, Franck P, Morisset M, Sainte Laudy J, Kanny G, Moneret-Vautrin DA. Pre-lethal anaphylaxis to carboxymethylcellulose confirmed by identification of specific IgE--review of the literature. Eur Ann Allergy Clin Immunol. 2009:41:171-6.

102. Neoh CY, Tan AW, Leow YH. Delayed hypersensitivity reaction after intravenous glucagon administered for a barium enema: a case report. Ann Acad Med Singapore. 2006;35:279-81.

103. Dillman JR, Ellis JH, Cohan RH, Strouse PJ, Jan SC. Frequency and severity of acute allergic-like reactions to gadoliniumcontaining i.v. contrast media in children and adults. AJR Am J Roentgenol. 2007;189:1533-8.

104. Jung JW, Kang HR, Kim MH, Lee W, Min KU, Han MH, Cho SH. Immediate hypersensitivity reaction to gadolinium-based MR contrast media. Radiology. 2012;264:414-22.

105. Prince MR, Zhang H, Zou Z, Staron RB, Brill PW. Incidence of immediate gadolinium contrast media reactions. AJR Am J Roentgenol. 2011;196:W138-43.

106. Davenport MS, Dillman JR, Cohan RH, Hussain HK, Khalatbari $\mathrm{S}$, McHugh JB, Ellis JH. Effect of abrupt substitution of gadobenate dimeglumine for gadopentetate dimeglumine on rate of allergic-like reactions. Radiology. 2013;266:773-82.

107. Idee JM, Gaillard S, Corot C. Gadolinium-bound Contrast Agents: No Evidence-based Data to Support a Relationship Between Structure and Hypersensitivity Reactions. Indian J Dermatol Venereol Leprol. 2012;57:245.

108. Takahashi S, Takada A, Saito K, Hara M, Yoneyama K, Nakanishi $H$. Fatal anaphylaxis associated with the gadolinium-based contrast agent gadoteridol (ProHance) J Investig Allergol Clin Immunol. 2015:25:365-84.

109. Beaudouin E, Kanny G, Blanloeil Y, Guilloux L, Renaudin JM, Moneret-Vautrin DA. Anaphylactic shock induced by gadoterate meglumine (DOTAREM). Eur Ann Allergy Clin Immunol. 2003;35:382-5.

110. Kalogeromitros DC, Makris MP, Aggelides XS, Spanoudaki N, Gregoriou SG, Avgerinou G, Rigopoulos DG. Anaphylaxis to gadobenate dimeglumine (Multihance): a case report. Int Arch Allergy Immunol. 2007;144:150-4.

111. Tomas M, Fuentes Aparicio V, Zapatero Remon L, Alonso Lebrero $E$, Infante Herrero S. Skin reactions to gadoliniumbased contrast media. J Investig Allergol Clin Immunol. 2012;22:292-3
112. Chiriac AM, Audurier Y, Bousquet PJ, Demoly P. Clinical value of negative skin tests to gadolinium contrast agents. Allergy. 2011;66:1504-6.

113. Kowalski ML, Asero R, Bavbek S, Blanca M, Blanca-Lopez N, Bochenek G, Brockow K, Campo P, Celik G, Cernadas J, Cortellini G, Gomes E, Niżankowska-Mogilnicka E, Romano A, Szczeklik A, Testi S, Torres MJ, Wöhrl S, Makowska J. Classification and practical approach to the diagnosis and management of hypersensitivity to nonsteroidal antiinflammatory drugs. Allergy. 2013;68:1219-32.

114. Papadopoulos NG, Agache I, Bavbek S, Bilo BM, Braido F, Cardona V, Custovic A, deMonchy J, Demoly P, Eigenmann P, Gayraud J, Grattan C, Heffler E, Hellings PW, Jutel M, Knol E, Lötvall J, Muraro A, Poulsen LK, Roberts G, SchmidGrendelmeier P, Skevaki C, Triggiani $M$, vanRee $R$, Werfel T, Flood B, Palkonen S, Savli R, Allegri P, Annesi-Maesano I, Annunziato F, Antolin-Amerigo D, Apfelbacher C, Blanca M, Bogacka E, Bonadonna P, Bonini M, Boyman O, Brockow K, Burney P, Buters J, Butiene I, Calderon M, Cardell LO, Caubet JC, Celenk S, Cichocka-Jarosz E, Cingi C, Couto M, deJong N, Del Giacco S, Douladiris N, Fassio F, Fauquert JL, Fernandez J, Fernandez Rivas M, Ferrer M, Flohr C, Gardner J, Genuneit J, Gevaert P, Groblewska A, Hamelmann E, Hoffmann HJ, Hoffmann-Sommergruber K, Hovhannisyan L, Hox V, Jahnsen FL, Kalayci Ö, Kalpaklioglu AF, Kleine-Tebbe J, Konstantinou G, Kurowski M, Lau S, Lauener R, Lauerma A, Logan Q, Magnan A, Makowska J, Makrinioti $H$, Mangina $P$, Manole $F$, Mari $A$, Mazon A, Mills C, Mingomataj EÇ, Niggemann B, Nilsson G, Ollert M, O'Mahony L, O'Neil S, Pala G, Papi A, Passalacqua G, Perkin M, Pfaar O, Pitsios C, Quirce S, Raap U, RaulfHeimsoth M, Rhyner C, Robson-Ansley P, Rodrigues Alves $\mathrm{R}$, Roje Z, Rondon C, Rudzeviciene 0 , Ruëff F, Rukhadze $M$, Rumi G, Sackesen C, Santos AF, Santucci A, Scharf C, SchmidtWeber C, Schnyder B, Schwarze J, Senna G, Sergejeva S, Seys S, Siracusa A, Skypala I, Sokolowska M, Spertini F, Spiewak R, Sprikkelman A, Sturm G, Swoboda I, Terreehorst I, Oskala E, Traidl-Hoffmann C, Venter C, Vlieg-Boerstra B, Whitacker P, Worm M, Xepapadaki $P$, Akdis CA. Research needs in allergy: an EAACI position paper, in collaboration with EFA. Clin Transl Allergy. 2012;2:21.

\section{Manuscript received December 21, 2015; accepted for publication February 19, 2016.}

\section{- Ana Rosado Ingelmo}

Unidad de Alergia

Hospital Universitario Fundación Alcorcón

c/ Budapest, 1

28922 Alcorcón, Madrid, Spain

E-mail: arosado@fhalcorcon.es 